\title{
Internal quality assurance in a clinical virology laboratory. I. Internal quality assessment
}

\author{
J J Gray, T G Wreghitt, T A McKee, P McIntyre, C E Roth, D J Smith, G Sutehall, \\ G Higgins, R Geraghty, R Whetstone, U Desselberger
}

\begin{abstract}
Aims-In April 1991 an internal quality assessment scheme (IQAS) was introduced into the virology section of the Clinical Microbiology and Public Health Laboratory, Cambridge. The IQAS was established to identify recurring technical and procedural problems, to check the adequacy of current techniques, and to calculate the frequency of errors.

Methods-Between April 1991 and December 1993, 715 anonymous clinical serum samples were submitted to the laboratory to test 3245 individual procedures of diagnostic viral serology. Results-A total of $485(14.9 \%)$ procedural and $61(1.9 \%)$ technical discrepancies were observed, the technical discrepancies mainly being recorded in complement fixation tests. Twenty two $(0 \cdot 7 \%$ of total procedures) of the technical discrepancies were diagnostically significant.

Conclusions-Evaluation criteria developed with the introduction of IQAS to viral serology, and technical and procedural discrepancies are assessed. As yet, IQAS has not been introduced to other sections of the diagnostic virology laboratory (virus isolation, electron microscopy, immunofluorescence, and enzyme linked immunosorbent assays for viral and chlamydial antigens).

(f Clin Pathol 1995;48:168-173)
\end{abstract}

Keywords: Quality assurance, quality assessment, clinical virology.

The management and control of quality in the clinical microbiology laboratory has evolved since the mid-1960s, from initially voluntary participation in quality assessment studies via professional establishment of quality assessment schemes to legislative measures on quality control requirements. ${ }^{12}$

Quality assurance is regarded as the overall approach of quality management indicators of health care outcome related to parameters of patient care. Subsections thereof are quality assessment schemes relating to proficiency testing of external and internal specimens, evaluations of internal quality controls and monitoring of laboratory equipment and working conditions.

Updates of such procedures have been given by Bartlett et $a l^{2}{ }^{2}$ Miller and Wentworth, ${ }^{3}$ Braunstein, ${ }^{4}$ Weissfeld and Bartlett, ${ }^{5}$ and August et $a l .{ }^{6}$ In most of these publications issues relating to clinical virology have been dealt with in a rather marginal way.

A comprehensive quality assurance scheme for use in a diagnostic virology laboratory should consist of several distinct components designed to monitor all areas of activity in the laboratory. The scheme should include external and internal quality assessment, the use of internal quality controls and the monitoring of equipment and reagents.

Microbiology laboratories have participated in a UK National External Quality Assessment Scheme (NEQAS) for many years. ${ }^{7}$ Although NEQAS distributions assess many different tests of the diagnostic virology section, they are relatively infrequent and carry a limited number of samples in each distribution. The results obtained in such a scheme can only reflect the quality of work in the laboratory at the time of distribution. The limited number of samples may bias the results, particularly if-although it is undesirable-NEQAS samples receive more attention than routine clinical samples. NEQAS mainly provides comparisons among laboratories, among detection systems and permits comprehensive discussion of such results and discrepancies.

An internal quality assessment scheme (IQAS) can be used to monitor the quality of work more frequently and reproduce normal test conditions more accurately that NEQAS. IQAS samples can be provided in sufficient numbers and should not be more vigorously tested that any other routine specimen.

In the IQAS some specimens received in the laboratory are resubmitted for testing anonymously, thus all activities involved in the passage of specimens through the laboratory starting from reception and ending in the dispatch of final report can be monitored. ${ }^{8}$ The samples chosen can realistically reflect the diversity of tests in current use, and the numbers can be sufficiently high to monitor all laboratory procedures with precision but without increasing the workload excessively.

Here, we report on the organisation and performance of an IQAS used in the diagnostic virology laboratory of the Clinical Microbiology and Public Heath Laboratory, Cambridge, since April 1991 to assess the performance of the serology section. For organisational reasons, antibodies against other microbiological agents (Chlamydia $\mathrm{sp}$, Coxiella burnetii, Mycoplasma pneumoniae, Legionella pneumophilia, Toxoplasma gondii) were also tested in this section. A total of 715 anonymous serum samples (IQAS) to test 3245 individual procedures were submitted between April 1991 and December 1993. 


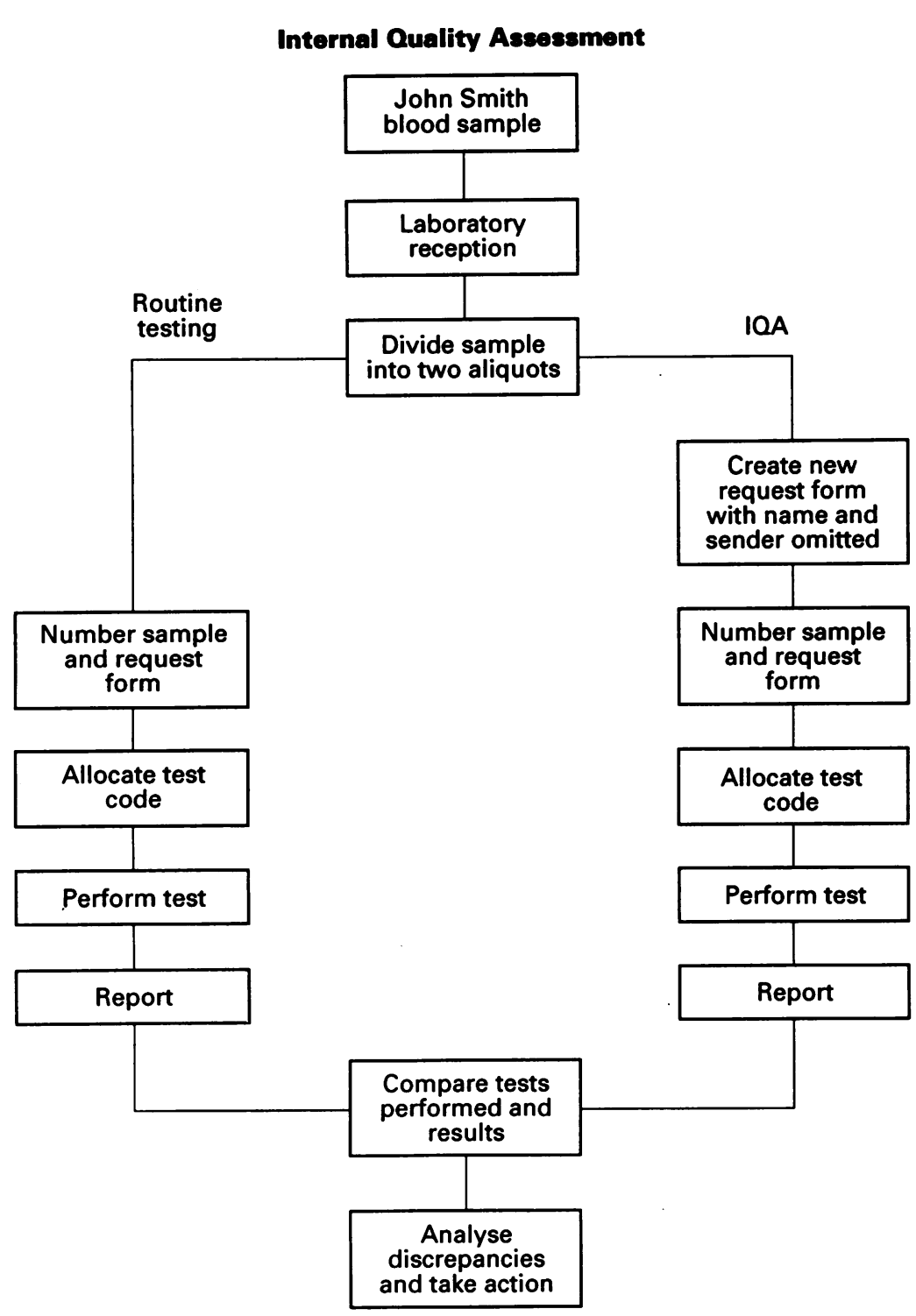

Algorithm for IQA. relevant result. All specimens were divided at entry. IQAS request forms, detailing sex and age of the patient and relevant clinical information, but not the patient's identification, were generated for the anonymous aliquots. The two samples were then entered into the laboratory system and processed according to routine procedures (figure). The anonymous samples, submitted as part of the IQAS, represented $0.75 \%$ of the total number of serology specimens received in 1991 (226 of 30133 ), $0.87 \%$ in 1992 (270 of 31034 ) and $0.66 \%$ in 1993 (219 of 33181 ).

Clinical computer codes were introduced to facilitate sample processing and storage, and calculation of workload statistics by computer. They were entered on each request form by the clinical virologist to identify the test or panel of tests required (table 1).

Rules governing the assessment of agreement or discrepancy must be sufficiently rigorous to distinguish significant differences between the procedures performed on, or the results obtained with, the named compared with the anonymous aliquot. Conversely, the rules must be flexible enough to take acceptable intra- and interassay variations into account.

Accordingly, at the inception of the IQAS a number of rules defining a discrepancy between the sample of the named patient and its corresponding anonymous aliquot were formulated. Technical discrepancies were recorded if there was a fourfold or greater difference in antibody titre between the two samples assayed by serial dilutions, if the difference in apparent concentration between the two samples was greater than the coefficient of variation for that assay, and if there was a discrepancy of positivity/negativity when single dilutions or undiluted samples were tested. Procedural discrepancies were recorded if different tests were performed on the two samples (each procedure carried out on one sample but not on the other would be counted as a discrepancy) and if the results obtained with the two samples were interpreted differently. Once recorded, all discrepancies were referred back to their source for comment and further testing if required.
INTERNAL QUALITY ASSESSMENT USING ANONYMOUS SAMPLES

Serum samples were either randomly selected on receipt or retrieved from storage in order to provide sufficient numbers for a clinically

Table 1 Examples of clinical computer codes used to analyse serum in the diagnostic virology laboratory

\begin{tabular}{llll}
\hline Code & Clinical indication & Assays performed & $\begin{array}{c}\text { Number of } \\
\text { procedures }\end{array}$ \\
\hline SO1 & HBsAg & HBsAg & 1 \\
SO2 & Acute hepatitis & HBsAg, hepatitis A IgG, hepatitis A IgM & 3 \\
SO6 & Hepatitis B immunity & anti-HBs & 1 \\
S11 & HIV & HIV 1+2 antibody (combined assay) & 1 \\
S35 & CNS encephalitis & VZV, HSV, mumps, measles and T gondii antibodies & 5 \\
S51 & Respiratory screen & Respiratory CFT screen*, L pneumophila antibodies & 7 \\
S53 & Lymphadenopathy & Respiratory CFT screen, T gondii and Paul-Bunnell & 8 \\
S54 & Lymphadenopathy & antibodies & 9 \\
S61 & Toxoplasma & Bunnell antibodies & \\
RSC & Rubella antibody screen & Tgondii antibody & 1 \\
VV5 & Store serum (more information & Rubella SRH & 1 \\
VV6 & requested) & None & 0 \\
VV9 & Send serum to reference laboratory and Paul- & \\
\end{tabular}

Note: Many of the clinical indications require further investigations - for example, viral culture from faeces or throat swabs from cases suspect of encephalitis, viral culture/direct immunofluorescence assays in cases of respiratory infection, etc. * Antibodies to influenza virus A, influenza virus B, adenovirus, Chlamydia $\mathrm{sp}, C$ burnetii, M pneumoniae.

HBsAg = hepatitis B surface antigen; VZV = varicella zoster virus; $\mathrm{HSV}=$ herpes simplex virus; $\mathrm{CMV}=$ cytomegalovirus; $\mathrm{CNS}=$ central nervous system; $\mathrm{SRH}=$ single radial haemolysis. 
For procedural and organisational reasons, the serology laboratory was divided into four sections: (i) complement fixation tests (CFTs), (ii) rubella virus serology, (iii) serology for HIV and hepatitis viruses, and (iv) other serology (including tests for detecting antibodies to $T$ gondii, L pneumophila, Epstein-Barr virus, cytomegalovirus, varicella zoster virus, herpes simplex virus, and parvovirus B19). Each section was under the supervision of a senior member of the technical staff. This managerial division was also maintained for the purposes of performance and evaluation of the IQAS.

Each specific antigen or antibody test performed was counted as one procedure. For instance, a sample submitted for a respiratory antibody screen (coded as S51; table 1) was tested in the CFT against influenza A virus, influenza B virus, adenovirus, Chlamydia $\mathrm{sp}, C$ burnetii, and $M$ pneumoniae antigens, and in the rapid microagglutination test for $L$ pneumophila antibodies resulting in a total of seven procedures being carried out on one sample.

\section{Results}

In 1991, 226 anonymous samples used to test 936 procedures were submitted; in 1992, 270 samples enabled testing of 1187 procedures, and in 1993, 219 samples enabled testing of 1122 procedures.
Procedural or coding discrepancies (table 2) were detected in $12 \cdot 1 \%$ of the procedures or 23 of $226(10.2 \%)$ of the samples tested in $1991 ; 9 \cdot 7 \%$ of the procedures or 23 of 270 $(8.5 \%)$ of the samples tested in 1992 , and $23.5 \%$ of the procedures or 35 of $219(16.0 \%)$ of the samples tested in 1993. Technical discrepancies were detected in $0.9 \%$ of the procedures in $1991,1.5 \%$ in 1992 and $3.0 \%$ in 1993 (table 2). Note that technical discrepancies were very unevenly distributed-for example, seven of nine in 1991 occurred in April only, eight out of 18 in 1992 were seen in May and August only, and 20 out of 34 in 1993 were recorded in February and March only (table 2 ). The reasons for this were investigated and will be discussed later. Procedural discrepancies were also unevenly distributed, but independently of technical discrepancies (table 2). Reasons for this will also be discussed later. A statistically significant increase $\left(\chi^{2}\right.$ test, $\left.\mathrm{p}<0.02\right)$ was seen in the number of procedural and technical discrepancies in 1993 when compared with those recorded 1992 and 1991 (table 2).

Between 1991 and 1993, 2028 of 3245 $(62.5 \%)$ of the IQAS procedures were performed in the CFT section (table 3) with 288 of $485(59.4 \%)$ of the total procedural or coding discrepancies and 47 of $61(77 \cdot 0 \%)$ of the total

Table 2 Procedural and technical discrepancies observed in IQAS samples

\begin{tabular}{|c|c|c|c|c|c|}
\hline \multirow[b]{2}{*}{ Month } & \multirow[b]{2}{*}{ Total } & \multicolumn{4}{|l|}{ Discrepancy } \\
\hline & & Procedural & Per cent & Technical & Per cent \\
\hline $\begin{array}{l}1991 \\
\text { April } \\
\text { May } \\
\text { June } \\
\text { July } \\
\text { August } \\
\text { September } \\
\text { October } \\
\text { November } \\
\text { December }\end{array}$ & $\begin{array}{r}112 \\
119 \\
69 \\
95 \\
101 \\
78 \\
139 \\
104 \\
119\end{array}$ & $\begin{array}{r}6 \\
4 \\
10 \\
1 \\
8 \\
6 \\
46 \\
15 \\
15\end{array}$ & $\begin{array}{r}7 \cdot 1 \\
3 \cdot 4 \\
14 \cdot 5 \\
1 \cdot 1 \\
7 \cdot 9 \\
7 \cdot 7 \\
33 \cdot 1 \\
14 \cdot 4 \\
12 \cdot 6\end{array}$ & $\begin{array}{l}7 \\
0 \\
0 \\
0 \\
0 \\
0 \\
0 \\
1 \\
1\end{array}$ & $\begin{array}{l}6 \cdot 3 \\
0 \cdot 0 \\
0 \cdot 0 \\
0 \cdot 0 \\
0 \cdot 0 \\
0 \cdot 0 \\
0 \cdot 0 \\
1 \cdot 0 \\
0 \cdot 8\end{array}$ \\
\hline Total & 936 & 111 & $12 \cdot 1$ & 9 & 0.9 \\
\hline $\begin{array}{l}1992 \\
\text { January } \\
\text { February } \\
\text { March } \\
\text { April } \\
\text { May } \\
\text { June } \\
\text { July } \\
\text { August } \\
\text { September } \\
\text { October } \\
\text { November } \\
\text { December }\end{array}$ & $\begin{array}{r}153 \\
95 \\
126 \\
126 \\
104 \\
137 \\
60 \\
62 \\
98 \\
93 \\
80 \\
53\end{array}$ & $\begin{array}{r}8 \\
0 \\
18 \\
18 \\
12 \\
0 \\
10 \\
9 \\
3 \\
21 \\
6 \\
10\end{array}$ & $\begin{array}{r}5 \cdot 2 \\
0 \cdot 0 \\
14 \cdot 3 \\
14 \cdot 3 \\
11.5 \\
0 \cdot 0 \\
16 \cdot 7 \\
14 \cdot 5 \\
3 \cdot 1 \\
22 \cdot 6 \\
7 \cdot 5 \\
18 \cdot 9\end{array}$ & $\begin{array}{l}1 \\
2 \\
1 \\
0 \\
4 \\
1 \\
0 \\
4 \\
1 \\
2 \\
2 \\
0\end{array}$ & $\begin{array}{l}0 \cdot 7 \\
2 \cdot 1 \\
0 \cdot 8 \\
0 \cdot 0 \\
3 \cdot 8 \\
0 \cdot 7 \\
0 \cdot 0 \\
6 \cdot 5 \\
1 \cdot 0 \\
2 \cdot 2 \\
2 \cdot 5 \\
00\end{array}$ \\
\hline Total & 1187 & 115 & $\begin{array}{c}9.7 \\
(\mathrm{p}<0.5)\end{array}$ & 18 & $\begin{array}{l}1.5 \\
(p<0.5)\end{array}$ \\
\hline $\begin{array}{l}1993 \\
\text { January } \\
\text { February } \\
\text { March } \\
\text { April } \\
\text { May } \\
\text { June } \\
\text { July } \\
\text { August } \\
\text { September } \\
\text { October } \\
\text { November } \\
\text { December }\end{array}$ & $\begin{array}{r}60 \\
95 \\
110 \\
105 \\
58 \\
66 \\
123 \\
92 \\
104 \\
131 \\
06 \\
82\end{array}$ & $\begin{array}{r}28 \\
9 \\
33 \\
13 \\
10 \\
1 \\
27 \\
47 \\
19 \\
38 \\
22 \\
12\end{array}$ & $\begin{array}{r}46 \cdot 6 \\
9 \cdot 5 \\
30 \cdot 0 \\
12 \cdot 4 \\
17 \cdot 2 \\
1.5 \\
22 \cdot 0 \\
51 \cdot 1 \\
18 \cdot 3 \\
29 \cdot 0 \\
22 \cdot 9 \\
14 \cdot 6\end{array}$ & $\begin{array}{r}2 \\
13 \\
7 \\
2 \\
0 \\
3 \\
4 \\
0 \\
1 \\
1 \\
1 \\
0\end{array}$ & $\begin{array}{r}3.3 \\
13.7 \\
6.4 \\
1.9 \\
0.0 \\
4.5 \\
3.3 \\
0.0 \\
1.0 \\
0.8 \\
1.0 \\
0.0\end{array}$ \\
\hline Total & 1122 & 259 & $\begin{array}{l}23.5 \\
(p<0.001)\end{array}$ & 34 & $\begin{array}{c}3.0 \\
(p<0.01)\end{array}$ \\
\hline $\begin{array}{c}1991-1993 \\
\text { Total }\end{array}$ & 3245 & 485 & 14.9 & 61 & 1.9 \\
\hline
\end{tabular}


Table 3 Number of IQA procedures tested in each laboratory section

\begin{tabular}{|c|c|c|c|c|}
\hline \multirow[b]{2}{*}{ Section } & \multirow[b]{2}{*}{ Total } & \multicolumn{2}{|c|}{ Number discrepant (\%) } & \multirow{2}{*}{$\begin{array}{l}\text { Significant technical } \\
\text { discrepancies (\%) }\end{array}$} \\
\hline & & Procedural & Technical & \\
\hline $\begin{array}{l}\text { CFT } \\
1991 \\
1992 \\
1993\end{array}$ & $\begin{array}{l}610 \\
746 \\
672\end{array}$ & $\begin{array}{c}75(12 \cdot 3) \\
58(7 \cdot 7) \\
155(23 \cdot 0)\end{array}$ & $\begin{array}{r}8(1 \cdot 3) \\
13(1 \cdot 7) \\
26(3 \cdot 8)\end{array}$ & $\begin{array}{l}3(0 \cdot 5) \\
3(0 \cdot 4) \\
7(1 \cdot 0)\end{array}$ \\
\hline Subtotal & 2028 & $288(14 \cdot 2)$ & $47(2 \cdot 3)$ & $13(0 \cdot 6)$ \\
\hline $\begin{array}{c}\text { Rubella serolo } \\
1991 \\
1992 \\
1993\end{array}$ & $\begin{array}{r}68 \\
100 \\
94\end{array}$ & $\begin{array}{l}5(7 \cdot 3) \\
2(2 \cdot 0) \\
5(5 \cdot 3)\end{array}$ & $\begin{array}{l}0(0 \cdot 0) \\
0(0 \cdot 0) \\
1(1 \cdot 1)\end{array}$ & $\begin{array}{l}0(0 \cdot 0) \\
0(0 \cdot 0) \\
0(0 \cdot 0)\end{array}$ \\
\hline Subtotal & 262 & $12(4 \cdot 6)$ & $1(0 \cdot 4)$ & $0(0 \cdot 0)$ \\
\hline $\begin{array}{l}\text { HIV/hepatitis } \\
1991 \\
1992 \\
1993\end{array}$ & $\begin{array}{l}145 \\
162 \\
115\end{array}$ & $\begin{array}{l}16(11 \cdot 0) \\
17(10 \cdot 5) \\
14(12 \cdot 2)\end{array}$ & $\begin{array}{l}0(0 \cdot 0) \\
4(2 \cdot 4) \\
1(0 \cdot 9)\end{array}$ & $\begin{array}{l}0(0 \cdot 0) \\
3(1 \cdot 8) \\
1(0 \cdot 9)\end{array}$ \\
\hline Subtotal & 422 & $47(11 \cdot 1)$ & $5(1 \cdot 2)$ & $4(0 \cdot 9)$ \\
\hline $\begin{array}{c}\text { Other serology } \\
1991 \\
1992 \\
1993\end{array}$ & $\begin{array}{l}113 \\
179 \\
241\end{array}$ & $\begin{array}{l}15(13 \cdot 3) \\
38(21 \cdot 2) \\
85(35 \cdot 3)\end{array}$ & $\begin{array}{l}1(0 \cdot 8) \\
1(0 \cdot 6) \\
6(2 \cdot 4)\end{array}$ & $\begin{array}{l}1(0 \cdot 8) \\
1(0 \cdot 6) \\
3(1 \cdot 5)\end{array}$ \\
\hline Subtotal & 533 & $138(25 \cdot 9)$ & $8(1 \cdot 5)$ & $5(0 \cdot 9)$ \\
\hline $\begin{array}{l}\text { Total } \\
\quad 1991-1993\end{array}$ & 3245 & $485(14 \cdot 9)$ & $61(1 \cdot 9)$ & $22(0 \cdot 7)$ \\
\hline
\end{tabular}

technical discrepancies being associated with these assays. Eight of nine $(88.8 \%)$ of the technical discrepancies in 1991,13 of 18 $(72 \cdot 2 \%)$ in 1992 , and 26 of $34(76.4 \%)$ in 1993 were detected in the CFT section. Of these, 28 of $47(59.6 \%)$ were associated with tests for $M$ pneumoniae (10 of 47), influenza virus (13 of 47 ; nine influenza $A$ and four influenza B) and Chlamydia sp antigens (five of 47) (table 4).

The technical discrepancies detected in hepatitis serology, rubella virus serology and other non-CFT serological tests between 1991 and 1993 are presented in table 5. There were no technical discrepencies associated with HIV serology, and all the discrepancies detected in hepatitis serology were found in the anti-HBs assay. Discrepancies were seen on more than one occasion in indirect immunofluorescence assays for detecting antibiodies to Epstein-Barr virus virus capsid antigen (VCA) and parvovirus B19. Discrepancies were also detected, on one occasion each, in a $M$ pneumoniae IgM antibody enzyme linked immunosorbent assay, (ELISA) a varicella zoster virus IgG antibody ELISA and in latex agglutination tests (LATs) for detecting antibodies to $T$ gondii and rubella virus.

Although fourfold or greater differences in the CFT antibody titre between the named sample and the anonymous aliquot were regarded as discrepant, it is also possible to discuss discrepancies on the basis of a "diagnostically significant" difference-for ex-

Table 4 Technical discrepancies in the CFT section in (a) 1991 and 1992 and (b) in 1993

\begin{tabular}{|c|c|c|c|c|c|c|c|}
\hline \multirow[t]{2}{*}{ (a) } & & & & \multicolumn{4}{|l|}{ (b) } \\
\hline & CFT antigen & $\begin{array}{l}\text { Named aliquot } \\
\text { titre }\end{array}$ & $\begin{array}{l}\text { Anonymous } \\
\text { aliquot titre }\end{array}$ & & CFT antigen & $\begin{array}{l}\text { Named aliquot } \\
\text { titre }\end{array}$ & $\begin{array}{l}\text { Anonymous } \\
\text { aliquot titre }\end{array}$ \\
\hline $\begin{array}{c}1991 \\
1 \\
2 \\
3 \\
4 \\
5 \\
6 \\
7 \\
8 \\
\\
1992 \\
9 \\
10 \\
11 \\
12 \\
13 \\
14 \\
15 \\
16 \\
17 \\
18 \\
19 \\
20 \\
21\end{array}$ & $\begin{array}{l}\text { HSV } \\
\text { Chlamydia } \\
\text { Yolk sac } \\
\text { CMV } \\
\text { M pneumoniae } \\
\text { Yolk sac } \\
\text { Measles } \\
\text { Chlamydia } \\
\\
\text { VZV } \\
\text { Adenovirus } \\
\text { Mpneumoniae } \\
\text { Mpneumoniae } \\
\text { M pneumoniae } \\
\text { CMV } \\
\text { Mumps S } \\
\text { Mpneumonia } \\
\text { Mumps S } \\
\text { Mumps V } \\
\text { M pneumoniae } \\
\text { Influenza A } \\
\text { Influenza B }\end{array}$ & $\begin{array}{l}1000 \\
<8 \\
<8 \\
32 \\
<8 \\
<8 \\
8 \\
<64 \\
\\
<8 \\
>256 \\
128 \\
<8 \\
128 \\
<8 \\
<8 \\
16 \\
16 \\
16 \\
<8 \\
32 \\
32\end{array}$ & $\begin{array}{r}16 \\
64 \\
8 \\
64 \\
32 \\
32 \\
32 \\
<8 \\
<8 \\
<8 \\
32 \\
<8 \\
<8\end{array}$ & $\begin{array}{l}1993 \\
22 \\
23 \\
24 \\
25 \\
26 \\
27 \\
28 \\
29 \\
30 \\
31 \\
32 \\
33 \\
34 \\
35 \\
36 \\
37 \\
38 \\
39 \\
40 \\
41 \\
42 \\
43 \\
44 \\
45 \\
46 \\
47\end{array}$ & $\begin{array}{l}\text { Influenza A } \\
\text { CMV } \\
\text { Influenza A } \\
\text { Influenza B } \\
\text { Adenovirus } \\
\text { Influenza A } \\
\text { Influenza B } \\
\text { Influenza B } \\
\text { Chlamydia } \\
\text { Adenovirus } \\
\text { M pneumoniae } \\
\text { Chlamydia } \\
\text { Influenza A } \\
\text { Adenovirus } \\
\text { M pneumoniae } \\
\text { Measles } \\
\text { M pneumoniae } \\
\text { Mumps S } \\
\text { Mumps V } \\
\text { Chlamydia } \\
\text { Yolk sac } \\
\text { Influenza A } \\
\text { Influenza A } \\
\text { Influenza A } \\
\text { Influenza A } \\
\text { M pneumoniae }\end{array}$ & $\begin{array}{l}32 \\
512 \\
<8 \\
<8 \\
<8 \\
<8 \\
<8 \\
<8 \\
<8 \\
<8 \\
<8 \\
32 \\
<8 \\
<8 \\
<8 \\
8 \\
8 \\
8 \\
<8 \\
256 \\
32 \\
64 \\
8 \\
>256 \\
128 \\
32\end{array}$ & $\begin{array}{l}<8 \\
64 \\
16 \\
32 \\
64 \\
64 \\
16 \\
32 \\
32 \\
128 \\
32 \\
128 \\
32 \\
32 \\
32 \\
64 \\
32 \\
32 \\
16 \\
16 \\
<8 \\
<8 \\
64 \\
64 \\
\mathbf{3 2} \\
\mathbf{1 2 8}\end{array}$ \\
\hline
\end{tabular}


Table 5 Technical discrepancies detected in hepatitis virus assays, rubella virus serology and other seology (non-CFT)

\begin{tabular}{|c|c|c|c|}
\hline Year & Test & Name aliquot & Anonymous aliquot \\
\hline $\begin{array}{l}1991 \\
1992\end{array}$ & $\begin{array}{l}\text { M pneumoniae IgM } \\
\text { VZV igG } \\
\text { anti-HBs } \\
\text { anti-HBs } \\
\text { anti-HBs } \\
\text { anti-HBs }\end{array}$ & $\begin{array}{l}\text { Positive* } \\
\text { Positive } \\
115 \mathrm{mlU} / \mathrm{ml} \\
86 \mathrm{mlU} / \mathrm{ml} \\
100 \mathrm{mlU} / \mathrm{ml} \\
102 \mathrm{mlU} / \mathrm{ml}\end{array}$ & $\begin{array}{l}\text { Not tested } \\
\text { Negative } \\
82 \mathrm{mlU} / \mathrm{ml} \\
107 \mathrm{mlU} / \mathrm{ml} \\
64 \mathrm{mlU} / \mathrm{ml} \\
97 \mathrm{mlU} / \mathrm{ml}\end{array}$ \\
\hline 1993 & $\begin{array}{l}T \text { gondii LAT } \\
\text { CMV IgG } \\
\text { EBV IgG } \\
\text { EBV iGG } \\
\text { Parvovirus B19 IgM } \\
\text { Parvovirus B19 IgM } \\
\text { anti-HBs } \\
\text { Rubella LAT }\end{array}$ & $\begin{array}{l}16 \\
>220 \mathrm{AU} / \mathrm{ml} \\
32 \\
128 \\
\text { Negative } \\
\text { Positive } \\
93 \mathrm{mlU} / \mathrm{ml} \\
64 \mathrm{IU} / \mathrm{ml}\end{array}$ & $\begin{array}{l}<16 \\
610 \mathrm{AU} / \mathrm{ml} \\
<8 \\
\mathbf{8} \\
\text { Positive } \\
\text { Negative } \\
120 \mathrm{ml} / \mathrm{ml} \\
256 \mathrm{IU} / \mathrm{ml}\end{array}$ \\
\hline
\end{tabular}

The "diagnostically significant" discrepancies are presented in bold.

* The named aliquot had a CFT titre of 64, satisfying our criteria for inclusion in the IgM assay. The anonymous sample had a CFT titre of 32 which did not satisfy those criteria.

$\mathrm{VZV}=$ varicella zoster virus; CMV = cytomegalovirus; EBV = Epstein-Barr virus.

ample, a comment could have been entered on the final report of only one of the two aliquots tested, highlighting the significance of a result even if only a twofold difference in antibody titre was found: "Adenovirus CFT : 64 (no comment entered). Adenovirus CFT : 128comment: may indicate recent adenovirus infection." This constitutes a "diagnostically significant" difference, whereas a fourfold difference in the lower range-for example, "Adenovirus CFT : 16 (no comment entered) Adenovirus CFT : 64 (no comment entered)" does not.

Similarly, when the two aliquots have been allocated different $S$ codes but the tests requested by the clinician are common to both codes (for example, S51 and S54 (see table 1) in a respiratory infection) there may not be a "diagnostically significant" difference.

Using these criteria to define discrepancies, there were 22 of $3245(0.7 \%)$ "diagnostically significant" technical discrepancies (bold in tables 4 and 5) compared with 61 of 3245 (1.9\%) total technical discrepancies (table 3 ). There was no statistically significant difference $(p<0.5)$ in the occurrence of significant technical discrepancies between 1991 and 1993.

Procedural discrepancies were detected in 81 of $715(11 \cdot 32 \%)$ samples. Discrepancies associated with 15 of these 81 samples were the result of failures in the conduct of the IQAS involving minor, but significant, differences in the information accompanying the named but not the anonymous sample. In a further 45 samples, recorded as discrepant through differences in the $S$ codes allocated to the two samples, the test spectra were not very different. Therefore "diagnostically significant" procedural discrepancies were detected in only 21 of $715(2.9 \%)$ samples and were associated with errors of transcription and omission (four of 21), significant coding differences (six of 21) or when only one of the two samples was tested (11 of 21).

\section{Discussion}

Participation in NEQAS betwen 1991 and 1993 did not indicate any problems with the serological assays used or the performance of those assays in the clinical diagnostic virology laboratory (data not shown). This may have been because NEQAS samples were treated differently although not in a concious way. ${ }^{9}$ Over the same period the internal quality assurance scheme was able to identify problem areas within the laboratory and helped to find solutions to these problems.

Random errors were detected in a wide range of assays, but lack of precision and accuracy was particularly identified in the CFT section. Forty seven of $2046(2 \cdot 3 \%)$ CFT procedures carried out on the anonymous samples were discrepant when a fourfold difference in antibody titre between the two samples was used to determine a significant difference. These results reflect the complexities involved in an assay that requires control and standardisation of six reactants: diluent, antibody, antigen, complement, haemolysin, and erythrocytes. The significant increase in technical discrepancies in February and March 1993 were found to be associated with a fault in the liquid handling device of an automatic pipetting machine used to serially dilute serum samples and to add antigen and complement in the CFT. When the fault was rectified, the number of discrepancies decreased immediately.

A significant number of technical discrepancies were also identified in indirect immunofluorescence assays for detecting Epstein-Barr virus VCA IgG and parvovirus B19 IgM antibodies. These discrepancies reflect the subjective nature of immunofluorence assays, particularly when weakly positive samples were tested.

Before 1993, the clinical computer codes reflected the "best fit" of tests required for any given clinical details. Additional tests, not covered by the chosen code, were until then added manually. Since the beginning of 1993, in an attempt to record and count all tests performed, the number and complexity of codes were increased to ensure that as many combinations of tests as possible were available to the clinical virologist. Although this permitted better accounting of the tests performed, it also created more codes which sometimes had only minor differences. Monthly differences in coding reflect differences in the application of these codes by different clinical virologists who were on a monthly rota at that time. The expansion of available codes resulted in the significant increase $(p<0.001)$ in procedural or coding discrepancies seen in 1993 compared with previous years and will decrease as more uniform use is made of these additional codes.

The rules, adopted at the outset of the IQAS to define discrepancies, have been modified in the light of experience, and a two tier system has now been introduced: the original rules are used to identify any possible discrepancies and then the "diagnostic significance" of such discrepancies is determined by taking into account the clinical significance of the discrepant result and how any differences would have affected patient management.

Therefore, between April 1991 and December 1993, "provisional" technical discrepancies were identified in 61 of 3245 (1.9\%) 
procedures but "diagnostically significant" technical discrepancies were detected in only 22 of $3245(0.7 \%)$ procedures. Provisional procedural or coding discrepancies were identified in 81 of $715(11.3 \%)$ samples, but of these only $21(2 \cdot 9 \%)$ were significant procedural discrepancies.

Most of the "diagnostically significant" procedural discrepancies (11 of 21) were recorded when one of the two samples was not tested. When the clinical information accompanying these samples was re-examined, it was found that in seven cases the patients presented with non-specific symptoms ranging from "generally unwell" to "chronic fatigue". These symptoms may be associated with a wide range of viral and non-viral infections making it difficult to choose the most appropriate test or tests to be performed, and thus the most appropriate clinical computer code. The remaining four samples, two from each of two consultants, were tested only when the requesting clinicians named appeared on the request form, even when the clinical information was identical. This indicated bias towards certain clinicians and was overcome in later samples by including the clinician's name on the request form accompanying the anonymous sample.

Although errors will inevitably occur, they can be significantly reduced through the introduction and use of a comprehensive IQAS. Training must be continually updated with regular meetings, to discuss quality control failures and successes, changes in standard operating procedures, the introduction of new assays, and the operation of new equipment. Publication of results within the laboratory and encouragement of staff to discuss technical problems and possible solutions can significantly improve the overall performance. Problems and inconsistencies in laboratory procedures can be identified through IQAS and continuous monitoring will increase the confidence in test results.

It is planned to extend the IQAS to cultivation of viruses in cell cultures, electron microscopic diagnosis and immunofluorescence assays and ELISA for antigen detection. In such cases it will be necessary to "spike" negative samples to achieve significant numbers of positive results.

The IQAS results in viral (and some other mircobial) serology show a lower discrepancy rate than those obtained with bacterial cultures in the same laboratory. ${ }^{8}$ This is most probably because the interpretation of bacterial culture results is more subjective and requires a high standard of training, whereas many of the serology procedures are automated.

The running and evaluation of the IQAS in the diagnostic virology laboratory has not been excessively laborious so far, particularly as much more time and effort may be required if major deficiencies are discovered by default. The cost of IQAS is estimated to be approximately 2 to $3 \%$ of total costs of running the laboratory. Quality assurance measures (including surveillance of equipment and working conditions) may be as much as 5 to $20 \%$ of total activity depending on size of the laboratory. ${ }^{10-12}$ Costs of quality assurance have to be related to the overall healthcare benefits derived from the measures introduced. ${ }^{12}$

The IQAS was run in conjunction with extended quality control procedures which involved the inclusion of internal quality controls in many of the assays used in the laboratory (see Part II).

We thank all staff of the Virology section of the Clinical Microbiology and Public Health Laboratory, Cambridge, for their support of the IQAS and for fruitful discussion. Thanks ar also due to M Farrington, H Ludlam, W Wilcox, D Brown, MAT Coles, and $M$ Amphlett for critical reading of the manuscript.

1 Federal Register, 1992;57:7002-288.

2 Bartlett RC, Mazens-Sullivan M, Tetreault JZ, Lobel S, Nivard J. Evolving approaches to management of quality in clinical microbiology. Clin Microbiol Reviews 1994;7: in clinical 88 .

3 Miller JM, Wentworth BB (eds). Methods for quality control in diagnostic mircrobiology. Washington DC: Amercian Public Health Association, 1985.

4 Braunstein H. Quality control in microbiology: a review and bibliography. Clin Lab Med 1986;6:649-75.

5 Weissfeld AS, Bartlett RC. Quality control. In: Howard BJ, Klass J, Weissfeld AS, Tinton RC, eds. Clinical and pathogenic microbiology, St Louis: CV Mosby, 1987:35-6.

6 August MJ, Hindler JA, Huber TW, Sewell DL. In: Weissfeld AS, ed. Quality control and quality assurance practices in clinical microbiology. Washington DC: American Society for Microbiology, 1990;1-14.

7 Snell JJS. External quality assessment. In: Senll JJS, Farrell ID, Roberts C, eds. Quality control: principles and practice in the microbiology laboratory. London: Public Health Laboratory Service, 1991:18-23.

8 Constantine CE, Amphlett M, Farrington M, Brown DFJ Messer S, Rampling A, et al. Development of an internal quality assessment scheme in a clinical bacteriology laboratory. $₹$ Clin Pathol 1993;46:1046-50.

9 Black WA, Dorse SE. A regional quality control program in microbiology. II. Advantages of simulated clinical specimens. Am f Clin Pathol 1976;66:407-15.

10 Barlett RL, Rutz CA, Konopacki N. Cost effectiveness of quality control in bacteriology. Am $\mathcal{f}$ Clin Pathol 1982;77: 184-90.

11 Barlett RC. Results of the survey of mircobiology laboratory management: summary and comments. Clin Microbiol Newsletter 1982;4:97-101.

12 Woo J, Schifreen RS, Winkelman JW. Controlling the cost of quality control. Clin Lab Med 1986;6:755-86. 